\title{
Length-weight relationship and prediction equations of body composition for growing-finishing cage-farmed Nile tilapia
}

\author{
Tarcila Souza de Castro Silva ${ }^{1}$, Lilian Dena dos Santos ${ }^{2}$, Lilian Carolina Rosa da Silva ${ }^{2}$, \\ Mariana Michelato ${ }^{3}$, Valéria Rossetto Barriviera Furuya ${ }^{4}$, Wilson Massamitu Furuya ${ }^{3,4}$
}

\author{
${ }^{1}$ Embrapa Agropecuária Oeste, Dourados, MS, Brasil. \\ 2 Universidade Federal do Paraná, Programa de Pós-graduação em Aquicultura e Desenvolvimento Sustentável, Palotina, PR, Brasil. \\ ${ }^{3}$ Universidade Estadual de Maringá, Programa de Pós-graduação em Zootecnia, Maringá, PR, Brasil. \\ ${ }^{4}$ Universidade Estadual de Ponta Grossa, Departamento de Zootecnia, Ponta Grossa, PR, Brasil.
}

\begin{abstract}
The objective of the present study was to develop models for predicting live weight from the lengthweight relationship and body composition of Nile tilapia. A total of 3,000 juvenile fish (initial weight $=28.6 \pm 4.16 \mathrm{~g}$ and standard length $=13.8 \pm 0.16 \mathrm{~cm})$ were distributed into three circular cages $\left(12 \mathrm{~m}^{3}\right.$ each $)$. The fish were hand-fed extruded diets containing $332 \mathrm{~g} \mathrm{~kg}^{-1}$ of crude protein and 3,230 kcal kg-1 of digestible energy, until apparent satiety, twice daily, for 100 days. Twelve fish were collected from each cage every 20 days for measurements of body weight and length, and proximate composition analysis; statistical analysis was conducted using linear regression. The value of the slope $b$ and the intercept for the length-weight relationship were 3.0604 and 0.0203 , respectively. The prediction equations obtained for body moisture (MO), crude protein $(\mathrm{CP})$, crude lipid (CL), and ash against body weight $(\mathrm{BW})$ in $\mathrm{g} / 100 \mathrm{~g}$ of fish were as follows: $\mathrm{MO}=70.0090-0.0071 \mathrm{BW} ; \mathrm{CP}=$ $13.7550+0.0037 \mathrm{BW} ; \mathrm{CL}=9.2636+0.0057 \mathrm{BW}$; and ash $=4.2392-0.0024 \mathrm{BW}$. It is possible to develop equations to predict body weight and composition, which can be used to control the production of Nile tilapia and improve its commercial value.
\end{abstract}

Key Words: amino acids, aquaculture, fish, mathematical modeling

\section{Introduction}

Mathematical models of fish growth offer an objective and practical method for describing patterns of growth data and estimating fish weight at times between sampling intervals. Accurate estimations of standing biomass, and therefore, of the amount of feed that must be provided, are vital to aquaculture management. Additionally, knowledge of the relationships between body weight and composition supports selection during efforts for the improvement of aquaculture genetics. An accurate length-weight relationship equation allows for the conversion of growth-in-length to growth-in-weight in stock assessment models, as well as the estimation of biomass from the length frequency distribution, condition (Petrakis and Stergiou, 1995), and morphological characteristics of fish populations (Stergiou and Moutopolous, 2001); the relationship equation, thus, is an important aquacultural management tool.

Growth, which is defined as a change in magnitude, can be measured in size and tissue composition and represents one of the most significant parameters in aquaculture. The

Received September 22, 2014 and accepted March 5, 2015.

Corresponding author: wmfuruya@uepg.br

http://dx.doi.org/10.1590/S1806-92902015000400001

Copyright (C) 2015 Sociedade Brasileira de Zootecnia. This is an Open Access article distributed under the terms of the Creative Commons Attribution Non-Commercial License, which permits unrestricted non-commercial use, distribution, and reproduction in any medium, provided the original work is properly cited. body composition of fish has recently received attention in studies on nutrition, genetics, and health (Tobin et al., 2006) because of the increasing interest in the quality and safety of fish products (Dumas et al., 2010). Body composition is an important aspect of nutritional quality (Kamal et al., 2007; Breck, 2014) and affects the nutritional value and consumption quality of fish (Azam et al., 2004). Despite the usefulness of the length-weight relationship and body composition, as well as the great economic importance of Nile tilapia (Oreochromis niloticus) to global aquaculture, little information on these factors is available in cagefarmed growing-finishing populations of the species. The present study was conducted to determine the lengthweight relationship and develop prediction equations of body composition for growing-finishing cage-farmed Nile tilapia by using regression analysis.

\section{Material and Methods}

The management was in accordance with the guidelines of the Animal Care Committee of Universidade Estadual de Maringá, Paraná, Brazil.

A total of 3,000 masculinized juvenile Nile tilapia (initial weight $=28.6 \pm 4.16 \mathrm{~g}$; standard length $=13.8 \pm 0.16 \mathrm{~cm}$; age, 60 days) were randomly distributed into three hexagonal cages ( $11 \mathrm{~m}^{3}$ each) placed at a local mean depth of $6.0 \pm 1.3 \mathrm{~m}$ in the Paranapanema River $\left(22^{\circ} 34^{\prime} 07^{\prime \prime S} ; 52^{\circ} 33^{\prime} 34^{\prime \prime} \mathrm{W}\right)$. A mix of 
vegetable and animal protein sources was used to formulate an extruded diet (Table 1) containing $332 \mathrm{~g} \mathrm{~kg}^{-1}$ of crude protein and $3,230 \mathrm{kcal} \mathrm{kg}^{-1}$ of digestible energy (Table 2). Crystalline amino acids were added to maintain the quantitative and essential amino acid profile recommended for Nile tilapia as described in NRC (2011). Fish were hand-fed to apparent satiety twice daily for 100 days. Water quality parameters were monitored daily during the feeding trial. The average water temperature was $28.5 \pm 1.3{ }^{\circ} \mathrm{C} ; \mathrm{pH}, 7.34 \pm 0.21$; and dissolved oxygen varied from 6.2 to $6.6 \mathrm{mg} \mathrm{L}^{-1}$.

At the beginning of the experiment and every 20 days afterwards, 12 fish were randomly selected from each cage, starved for $24 \mathrm{~h}$ and collected to determine individual weight, standard length, and whole-body composition. Whole-body samples of fish were pooled, ground, and stored at $-20{ }^{\circ} \mathrm{C}$ for proximate analysis.

Table 1 - Formulation of the experimental diet

\begin{tabular}{lc}
\hline Ingredient & $\mathrm{g} \mathrm{kg}^{-1}$ \\
\hline Corn flour & 59.7 \\
Soybean meal & 157.0 \\
Wheat bran & 167.5 \\
Sorghum flour & 199.9 \\
Meat and bone meal & 119.5 \\
Fish meal & 75.0 \\
Poultry by-products meal & 164.5 \\
Bean flour & 45.0 \\
DL-methionine & 2.5 \\
Choline chloride & 2.6 \\
Ascorbic acid & 0.7 \\
Mineral and vitamin mix $^{1}$ & 1.1 \\
Salt & 5.00 \\
\hline
\end{tabular}

${ }^{1}$ Composition per kg: vitamin $\mathrm{A}=20,000,000 \mathrm{IU}$; vitamin $\mathrm{D}_{3}=6,400,000 \mathrm{IU}$; vitamin $\mathrm{E}=160,000,000 \mathrm{IU}$; vitamin $\mathrm{K}_{3}=15,000,000 \mathrm{mg}$; vitamin $\mathrm{B}_{1}=15,000,000 \mathrm{mg}$; vitamin $B_{2}=20,000,000 \mathrm{mg}$; vitamin $B_{6}=16,000,000 \mathrm{mg}$; vitamin $B_{12}=14,000,000 \mathrm{mg}$; folic acid $=3,000 \mathrm{mg}$; pantothenic acid $=11,000,000 \mathrm{mg}$; biotin $=100,000,000 \mathrm{mg}$; choline $=142,000 \mathrm{mg}$; niacin $=200,000,000 \mathrm{mg}$; iron $=48 \mathrm{mg}$; copper $=24 \mathrm{mg}$; manganese $=36 \mathrm{mg}$; iodine $=6 \mathrm{mg}$; selenium $=0.48 \mathrm{mg}$.

Table 2 - Analyzed composition of the experimental diet $\left(\mathrm{g} \mathrm{kg}^{-1}\right.$ as fed basis)

\begin{tabular}{lc}
\hline Parameter & $\mathrm{g} \mathrm{kg}^{-1}$ \\
\hline Dry matter & 922.1 \\
Gross energy $\left(\mathrm{kcal} \mathrm{kg}^{-1}\right)$ & 4240.0 \\
Crude protein & 332.1 \\
Ether extract & 46.4 \\
Crude fiber & 33.4 \\
Ash & 94.1 \\
Calcium & 17.2 \\
Total phosphorus & 9.1 \\
Lysine & 15.3 \\
Arginine & 20.6 \\
Histidine & 6.2 \\
Isoleucine & 11.4 \\
Leucine & 22.2 \\
Methionine & 6.5 \\
Methionine + cystine & 11.2 \\
Phenylalanine + tyrosine & 23.1 \\
Threonine & 11.0 \\
Valine & 14.6 \\
\hline
\end{tabular}

The proximate composition analyses of the fish samples were performed following the procedures of the AOAC (1990). Water content was determined by placing the fish in a previously weighed aluminum foil tray, drying in an electric oven at $55^{\circ} \mathrm{C}$ until constant weight was achieved, and then oven-drying at $105{ }^{\circ} \mathrm{C}$ for $24 \mathrm{~h}$. Crude protein (nitrogen $\times 6.25$ ) was determined using the micro-Kjeldahl method after acid hydrolysis. Lipid was extracted using petroleum ether in a Soxhlet apparatus and determined gravimetrically. Ash was determined by combustion at $550^{\circ} \mathrm{C}$ in a muffle furnace for $6 \mathrm{~h}$.

Gross energy was determined using an adiabatic bomb calorimeter. Dietary amino acids were analyzed by hydrolyzing $0.3 \mathrm{mg}$ fish sample in $1 \mathrm{~mL}$ of $6 \mathrm{~N} \mathrm{HCl}$ for $22 \mathrm{~h}$. The obtained sample was diluted in $0.02 \mathrm{~N} \mathrm{HCl}$ and injected in an automatic Amino Acid Analyzer. Recovery hydrolysis was performed in $4 \mathrm{~N}$ methanesulfonic acid for the analysis of tryptophan and in performic acid for the recovery of sulfur amino acids.

Data on the total body length (L) and body weight were recorded from each fish. The parameters $a$ and $b$ of the length-weight relationship were estimated by logarithmic transformation of the equation $W=a \times L^{\mathrm{b}}$, in which $W$ is the body weight (g); $L$ is the standard body length $(\mathrm{cm}) ; a$ is the intercept; and $b$ is the slope. Length-weight relationships were used to provide the condition of fish and determine whether growth is isometric $(b=3)$ or allometric (negative allometric: $b<3$, or positive allometric: $b>3$ ) (Ricker, 1973). To check whether the average $b$ value was significantly different from 3.0 , the $t$-test was conducted at 0.05 significance. All statistical analyses were performed using the statistical package SPSS 14.0. The body composition data were analyzed by oneway analysis of variance (ANOVA) at a significance level of $\mathrm{p}<0.05$. The prediction equations for body composition were developed using linear $\left(\hat{y}_{i}=\beta_{0}+\beta_{1} x_{i}\right)$ or second-order $\left(\hat{y}_{i}=\beta_{0}+\beta_{1} x_{i}+\beta_{1} x_{i}^{2}\right)$ polynomial regression analysis (Zeiton et al., 1976). The degree of association between the variables was analyzed according to the determination coefficient $\left(\mathrm{r}^{2}\right)$ for each variable.

\section{Results and Discussion}

At the end of the experiment, a high daily weight gain (7.5 g) was observed (Table 3). Although indoor experiments offer uniform chemical and physical waterquality parameters that can be controlled, the advantage of conducting experiments in rivers is the high rates of water turnover, resulting in high and constant levels of dissolved oxygen and water temperature, which allow for a high daily weight gain in fish. The daily weight gain of fish in the 
present study was higher than that reported by Moraes et al. (2009) for Nile tilapia reared in indoor cages at the same density. Factors such as diet composition (Moraes et al., 2009), stocking density (Araujo et al., 2010), and chemical and physical parameters of the water may affect the fish growth; however, the higher weight gain of fish in this study was because the fish were fed until apparent satiation. Feed intake is a major factor for tilapia growth (Tran-Duy et al., 2012), and in our study, fish preferred to be fed to apparent satiation because of the constant and high dissolved oxygen concentration during trial studies. Besides this, all essential amino acids were supplied to meet the dietary requirement of Nile tilapia, as described in NRC (2011) based on the ideal-protein concept, to optimize protein (amino acids) utilization for fish growth and health (Li et al., 2009).

The length-weight relationship was established using the equation $\mathrm{W}=0.0203 \times \mathrm{L}^{3.0604}\left(\mathrm{R}^{2}=0.9914\right)($ Figure 1$)$. The mean value of $b$ (3.0604) did not significantly differ $(\mathrm{P}<0.05)$ from the standard value of 3.0, implying that the "cube law" could be applied for this species (Ricker, 1973). When the weigh-length exponent $b$ is equal to 3.0, the body form maintains a constant proportion to the length and the fish grows isometrically, resulting in an ideal shape (Pauly, 1983). However, when $b$ is less than 3.0, the fish shows negative allometric growth, and when the $b$ value is greater than 3.0, the fish shows positive allometric growth (Weatherley and Gill, 1987). Similar results were obtained for Nile tilapia collected from the Atbara River and Khashm El-Girba reservoir by Ahmed et al. (2011), who found a $b$ value higher than 3.0 (3.415) for this species. Thus, the fish are expected to grow proportionally in all directions.

Changes in fish weight are generally greater than those in fish length (Ahmed et al., 2011). In general, when the value of $b$ exceeds 3.0, fish become fatter, and when the value falls below 3.0, fish become leaner. The value of $b$ found in the present study is within the interval of 2.5 to 3.5 recorded for many fish species by Froese (2006), as well as between the values of 2.299 and 3.684 recorded for Nile tilapia in the Atbara River and Khashm El-Girba reservoir, respectively (Ahmed et al., 2011). However, this value is slightly higher than the mean value $(b=2.908)$ described by Britton and Harper (2008) for Nile tilapia with 4.0-23.1 cm in length.

All linear regressions were significant, with coefficients of determination $\left(\mathrm{r}^{2}\right)$ ranging from 0.7743 to 0.8628 . The relationships between body weight and body moisture, crude protein, and crude lipid were best expressed using linear regression analysis (Table 4). As shown in several studies, when the size of fish increase, more fat is deposited than the formation of other tissues (Salam and Davies, 1994; Salam et al., 2001). The compositions of various organs and bodily tissues may also show considerable differences (Weatherly and Gill, 1987). However, whole-body composition follows a similar pattern among different species as fish size increases (Lupatsch et al., 2001; Dumas et al., 2010), and the live weight of the majority of fishes consists of approximately $700-800 \mathrm{~g} \mathrm{~kg}^{-1}$ of water, $200-300 \mathrm{~g} \mathrm{~kg}^{-1}$ of protein, and 20-120 $\mathrm{g} \mathrm{kg}^{-1}$ of lipid (Love, 1980).

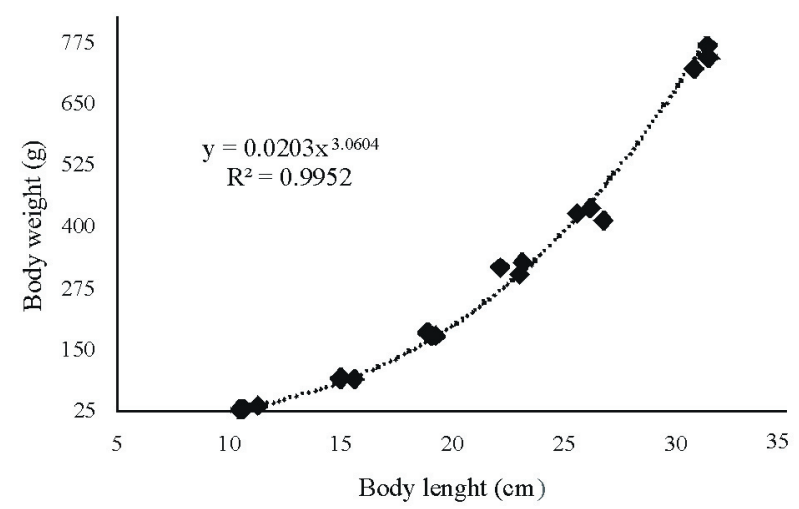

Figure 1 - Length-weight relationship of growing-finishing cagefarmed Nile tilapia (Oreochromis niloticus).

Table 3 - Growth and body composition (g $100 \mathrm{~g}^{-1}$ wet weight basis) of growing-finishing cage-farmed Nile tilapia (Oreochromis niloticus $)^{1}$

\begin{tabular}{|c|c|c|c|c|c|c|}
\hline \multirow[b]{2}{*}{ Variable } & \multicolumn{6}{|c|}{ Days of culture } \\
\hline & 1 & 20 & 40 & 60 & 80 & 100 \\
\hline \multicolumn{7}{|l|}{ Growth } \\
\hline Body weight (g) & $28.6 \pm 4.2$ & $88.6 \pm 1.4$ & $177.6 \pm 3.6$ & $313.8 \pm 12.8$ & $423.7 \pm 12.7$ & $774.4 \pm 23.6$ \\
\hline Standard length $(\mathrm{cm})$ & $10.9 \pm 0.4$ & $15.3 \pm 0.4$ & $19.1 \pm 0.2$ & $22.8 \pm 0.5$ & $26.3 \pm 0.6$ & $31.3 \pm 0.4$ \\
\hline \multicolumn{7}{|l|}{ Body composition } \\
\hline Moisture & $70.0 \pm 1.2$ & $69.1 \pm 0.7$ & $69.2 \pm 0.6$ & $67.2 \pm 0.4$ & $67.1 \pm 0.6$ & $65.1 \pm 0.2$ \\
\hline Crude protein & $14.2 \pm 0.4$ & $13.5 \pm 0.4$ & $14.5 \pm 0.4$ & $15.1 \pm 0.2$ & $15.3 \pm 0.5$ & $16.3 \pm 0.6$ \\
\hline Crude lipid & $8.6 \pm 0.3$ & $10.1 \pm 0.6$ & $10.5 \pm 0.3$ & $11.5 \pm 0.3$ & $12.1 \pm 0.7$ & $12.8 \pm 0.4$ \\
\hline Ash & $4.2 \pm 0.4$ & $4.2 \pm 0.2$ & $3.5 \pm 0.5$ & $3.6 \pm 0.2$ & $3.5 \pm 0.4$ & $2.4 \pm 0.1$ \\
\hline
\end{tabular}

${ }^{1}$ Values represent the mean \pm standard deviation of three replicate groups. 
The whole-body composition of fish is affected by species (Ali et al., 2005), environmental parameters (Ali et al., 2001), nutrition, and body size (Ebrahimi and Ouraji, 2012). Information on body composition related to fish size can be used to select fish with higher protein contents at a specific size, for human consumption (Ali et al., 2005). Fish represents one of the main sources of protein in developing countries (Louka et al., 2004). The moisture content is a good indicator of body protein and lipid contents (Ali et al., 2005), as observed in this study (Figure 2); lower moisture percentages are associated with higher lipid contents in fish (Dempson et al., 2004). Hartman and Margraf (2008) reported a significant fat-water relationship and developed models to predict the proximate composition for chum salmon (Oncorhynchus keta), rainbow trout (Oncorhynchus tshawytscha), brook trout (Salvelinus fontinalis), and striped bass (Morone saxatilis).

In the present study, moisture and ash contents decreased linearly with the increase in body weight. However, the body fat content increased linearly as a function of body weight. This result is in agreement with that described by Salam et al. (2001), who observed an increase in fat content with increase in the size of Nile tilapia. Memid et al. (2006) reported that the body constituents of Russian sturgeon (Acipenser gueldenstaedtii) could be estimated with reasonable accuracy from the weight of the fish by using

Table 4 - Number of studied fish (n), intercept $\left(\beta_{0}\right)$, slope $\left(\beta_{1}\right)$, P-values, and correlation coefficients of body composition parameters for growing-finishing cagefarmed Nile tilapia (Oreochromis niloticus)

\begin{tabular}{lcrrrc}
\hline Variable & $\mathrm{n}$ & \multicolumn{1}{c}{$\beta_{0}$} & \multicolumn{1}{c}{$\beta_{1}$} & P-value & $\mathrm{r}^{2}$ \\
\hline Moisture & 18 & 70.0090 & -0.0071 & $<0.05$ & 0.8628 \\
Crude protein & 18 & 13.7550 & 0.0037 & $<0.05$ & 0.7743 \\
Crude lipid & 18 & 9.2636 & 0.0057 & $<0.05$ & 0.8107 \\
Ash & 18 & 4.3280 & -0.0025 & $<0.05$ & 0.8189 \\
\hline
\end{tabular}

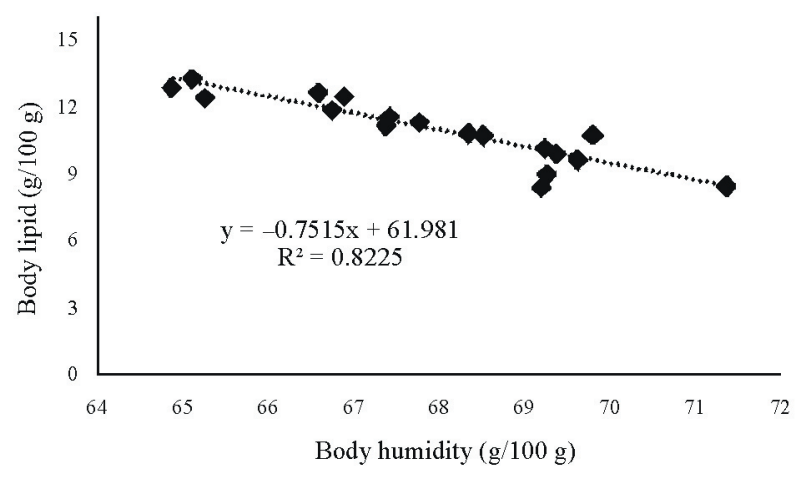

Figure 2 - Linear regression of body moisture against crude lipid for growing-finishing cage-farmed Nile tilapia (Oreochromis niloticus). a predictive regression model. Pangle and Sutton (2005) described a linear regression model for estimating temporal changes in the proximate composition of juvenile lake herring (Coregonus artedi) during winter periods. Breck (2014) reviewed the close relationship of body size to body composition for many freshwater and marine fish species. Understanding the relationship between body weight and length, as well as developing prediction equations for body composition, provide important support for genetic improvement, fish management, feeding strategies, and marketing.

\section{Conclusions}

The body composition of Nile tilapia varies according to its body weight and can be estimated using the lengthweight relationship. Prediction equations of body composition derived from linear regression analysis can be employed to address the requirements of specific consumer markets.

\section{Acknowledgments}

Financial support: Conselho Nacional de Desenvolvimento Científico e Tecnológico (CNPq) and Ajinomoto do Brasil Indústria de Comércio de Alimentos - Animal Nutrition Division for the amino acids donation and analysis. We wish to thank the staff of the "São João" fish farm group for allowing us the use the Fish Farm base, and Mr. Manuel Silva and Mrs. Rosa Silva for their support during this study.

\section{References}

Ahmed, E. O.; Ali, M. E. and Aziz, A. A. 2011. Length-weight relationships and condition factors of six fish species in Atbara River and Khashm el- girba Reservoir, Sudan. International Journal of Agricultural Science 3:65-70.

Ali, M.; Salam, A. and Iqbal, F. 2001. Effect of environmental variables on body composition parameters of Channa punctata. Journal of Research (Science) 12:200-206.

Ali, M.; Iqbal, F.; Salam, A.; Iram, S. and Athar, M. 2005. Comparative study of body composition of different fish species from brackish water pond. International Journal of Environmental Science and Technology 2:359-364.

AOAC - Association of Official Analytical Chemistry. 1990. Official methods of analysis. 15th ed. AOAC International, Arlington, VA.

Araujo, G. S.; Rodrigues, J. A. G.; Da Silva, J. W. A. and Farias, W. R. L. 2010. Cultivo da tilápia do Nilo em tanques-rede circulares em diferentes densidades de estocagem. Bioscience Journal 26:428-434.

Azam, K.; Ali, M. Y.; Asaduzzaman, M.; Basher, M. Z. and Hossain, M. M. 2004. Biochemical Assessment of Selected Fresh Fish. Journal of Biological Sciences 4:9-10. 
Breck, J. E. 2014. Body composition in fishes: body size matters. Aquaculture 433:40-40.

Britton, J. R. and Harper, D. M. 2008. Juvenile growth of two tilapia species in Lakes Naivasha and Baringo, Kenya. Ecology of Freshwater Fish 17:481-488.

Dempson, J. B.; Schwar, Z. C. J.; Shears, M. and Furey, G. 2004. Comparative proximate body composition of Atlantic salmon with emphasis on parr from fluvial and lacustrine habitats. Journal of Fish Biology 64:1257-1271.

Dumas, A.; France, J. and Bureau, D. 2010. Modeling of growth and body composition in fish nutrition: where have we been and where are we going? Aquaculture Research 41:161-181.

Ebrahimi, I. G. and Ouraji, H. 2012. Growth performance and body composition of kutum fingerlings, Rutilus frisii kutum (Kamenskii, 1901), in response to dietary protein levels. Turkish Journal of Zoology 36:551-558.

Froese, R. 2006. Cube law, condition factor and weight-length relationships: history, meta-analysis and recommendations. Journal of Applied Ichthyology 22:241-253.

Hartman, K. J. and Margraf, F. J. 2008. Common relationships among proximate composition components in fishes. Journal of Fish Biology 73:2352-2360.

Kamal, R.; Khan, A. N.; Rahman, M. A. and Ahamed. F. 2007. Biochemical composition of some small indigenous fresh water fishes from the river Mouri, Klulna, Bangladesh. Pakistan Journal of Biological Sciences 10:1559-1561.

Li, P.; Mai, K.; Trushenski, J. and Wu, G. 2009. New developments in fish amino acid nutrition: towards functional and environmentally oriented aquafeeds. Amino Acids 37:43-53.

Louka, N.; Juhel, F.; Fazilleau, V. and Loonis, P. 2004. A novel colorimetry analysis used to compare different drying fish processes. Food Control 15:327-334.

Love, R. M. 1980. The chemical biology of fishes. Academic Press, New York.

Lupatsch, I.; Kissil, G. W. and Sklan, D. 2001. Optimization of feeding regimes for European sea bass Dicentrarchus labrax: a factorial approach. Aquaculture 202:289-302.

Memid, D.; Celikkale, M. S. and Ercan, E. 2006. Effects of different diets on growth performance and body composition of Russian sturgeon (Acipenser gueldenstaedtii, Brandt \& Ratzenburg, 1833). Journal of Applied Ichthyology 22:287-290.
Moraes, A. M.; Seiffert, W. Q.; Tavares, F. and Fracalossi, D. M. 2009. Desempenho zootécnico de tilápia do Nilo, Oreochromis niloticus, em tanques-rede, com diferentes rações comerciais. Revista Ciência Agronômica 40:388-395.

NRC - National Research Council. 2011. Nutrient requirements of fish and shrimp. National Academy Press, Washington, DC.

Pangle, K. L. and Sutton, T. M. 2005. Temporal changes in the relationship between condition indices and proximate composition of juvenile Coregonus artedi. Journal of Fish Biology 66:1060-1072.

Pauly, D. 1983. Some simple methods for the assessment of tropical fish stocks. FAO Fisheries Technical Paper No. 234. FAO, Rome.

Petrakis, G. and Stergiou, K. I. 1995. Weight length relationships for 33 fish species in Greek waters. Fisheries Research 21:465-469.

Salam, A.; Ali, M. and Anas, M. 2001. Body composition of Oreochromis nilotica in relation to body size and condition factor. Pakistan Journal of Research Sciences 12:19-23.

Ricker, W. E. 1973. Linear regression in fisheries research. Journal of the Fisheries Research Board of Canada 30:409-434.

Salam, A. and Davies, P. M. 1994. Body composition of northern pike (Esox lucius L.) in relation to body size and condition factor. Fisheries Research 19:193-204.

Stergiou, K. I. and Moutopoulos, D. K. 2001. A review of lengthweight relationship of fishes from Greek marine waters. Naga: ICLARM Q, 24:23-39.

Tobin, D.; Kause, A.; Mntysaari, E. A.; Martin, S. A. M.; Houlihan, D. F.; Dobly, A.; Kiessling, A.; Rungruangsak-Torrissen, K.; Ritola, O. and Ruohonen, K. 2006. Fat or lean? The quantitative genetic basis for selection strategies of muscle and body composition traits in breeding schemes of rainbow trout (Oncorhynchus mykiss). Aquaculture 261:510-521.

Tran-Duy, A.; Van Dam, A. A. and Schrama, J. W. 2012. Feed intake, growth and metabolism of Nile tilapia (Oreochromis niloticus) in relation to dissolved oxygen concentration. Aquaculture Research 43:730-744.

Weatherley, A. H. and Gill, H. S. 1987. The biology of fish growth. Academic Press, London.

Zeiton, I. H.; Ullrey, D. E. and Magee, W. T. 1976. Quantifying nutrient requirements for fish. Journal of the Fisheries Research Board of Canada 33:167-172. 